\title{
Universities and sustainable regional development: introduction to the special issue
}

\author{
Lorenz Blume ${ }^{1}$ - Thomas Brenner ${ }^{2}$ Guido Buenstorf ${ }^{3,4,5}$
}

Accepted: 9 September 2017 / Published online: 4 October 2017

(C) Springer-Verlag GmbH Germany 2017

\section{Introduction: universities and sustainable regional development}

Universities matter to the development of their host regions. This insight is anything but new, as countless studies demonstrate the positive impact of universities on their regional environment. To some extent this is hardly surprising. For centuries governments all over Europe, and also in other parts of the world, have funded existing universities and initiated the establishment of new ones. This support was often linked to useful university outputs. For instance, educating civil servants constituted one of the earliest tasks of European universities, and 19th century technical universities were primarily established to safeguard the supply of human capital for the emerging science-based industries (Hüther and Krücken 2016).

Systematic empirical research into the effects of universities on their host regions likewise has a long tradition. Initially, much of this research focused on how the expenditures of universities, faculty, staff and students affect their host regions through direct and indirect "demand-side" effects of consumption and investment. Time and again, researchers estimated these effects to be substantial (cf. Drucker and Goldstein 2007 , for a survey). It is similarly well-established that universities exert "supplyside" effects through the production of graduates (Stephan 2012). More recently the

T. Brenner

thomas.brenner@uni-marburg.de

1 Economics Department, Philipps University Marburg, Marburg, Germany

2 Department of Geography, Philipps University Marburg, Deutschhausstr. 10, 35032 Marburg, Germany

3 Department of Economics and INCHER-Kassel, University of Kassel, Kassel, Germany

4 IWH Leibniz Institute of Economics Halle, Halle, Germany

5 Institute of Innovation and Entrepreneurship, University of Gothenburg, Gothenburg, Sweden 
scholarly interest in universities' supply-side effects shifted from graduates to innovation and entrepreneurship. Underlying this shift are an enhanced societal interest in universities as knowledge providers as well as the observation that the impact of universities on private-sector innovation tends to be localized. Case study evidence supporting the notion of universities as important players in regional innovation systems abounds. Many observers have noted the role that Stanford University, and also UC Berkeley, played in Silicon Valley's ascent to become the global center of the computer industry and related high-tech activities (e.g., Kenney and Mowery 2014; Klepper 2016). As documented by Powell et al. (2012), university research and academic entrepreneurship were perhaps even more decisive in the emergence and evolution of U.S. biotechnology clusters, and similar observations have been made elsewhere. Moving from individual cases to a more aggregate econometric approach, the impact of university research on regional innovation was shown in numerous empirical contexts including, e. g., the U.S. (Jaffe 1989; Acs et al. 1992), Germany (Fritsch and Slavtchev 2007; Schubert and Kroll 2014), or Italy (Cowan and Zinovyeva 2013). These findings are corroborated at a global scale by Valero and Van Reenen (2016), and many other references could be provided.

Why then this special issue, if so much has already been written about the regional effects of universities? Put simply, the answer is: because new challenges to universities and society at large generate new questions for research. Particularly in continental Europe, both the university itself and societal expectations regarding its activities and outputs have changed drastically in the past decades. Whereas European universities tended to be loosely coupled assemblies of experts dominated by professorial self-governance, they increasingly have been transformed into strategically managed organizations that pursue organizational objectives and compete with one another (Hüther and Krücken 2016). This development is associated with, and reinforced by, policy makers' quests to ensure that public universities contribute to societal goals as best they can. To this end, the efficiency of universities is targeted by New Public Management (e.g., Vogel 2006), and knowledge transfer to the private sector has been established as universities' "third mission" (Etzkowitz and Leydesdorff 2000) besides teaching and doing research. As part of the increased scrutiny under which contemporary universities find themselves, performance rankings and performance-based funding schemes have proliferated (e.g., Welpe et al. 2015). At the same time, universities' global competitiveness based on academic "excellence" is increasingly highlighted, and large-scale policy measures to make universities more "excellent" have diffused widely (e. g., Hazelkorn 2009; Hird and Pfotenhauer 2017).

In a broader definition of the "third mission" universities are also expected to engage in their region's social and societal deliberation and decision-making processes (Chatterton and Goddard 2000; Breznitz and Feldman 2012). In this context, sustainability has become an important issue. However, the definitions of what sustainability means are still diverse (see Pike et al. 2007, for a comprehensive discussion). Agreement exists on the belief that sustainability should encompass economic, but also social and environmental objectives (Brundtland 1987).

These new demands on universities often reflect broader challenges that Western societies and states (which traditionally operate most universities in Continental 
Europe) have seen themselves confronted with. Challenged by tight public budgets, policy makers naturally targeted the efficiency of university operations. In light of structural change in Western economies and increased international competition to domestic producers, perceived shortcomings in private-sector innovation have gained attention, and the lack of interaction between universities and companies has been identified as one of their causes (cf., e.,g., Dosi et al. 2006, for a discussion of the alleged "European paradox"). Similar to the realm of knowledge transfer, policy makers have often perceived continental European universities as being outperformed by their U.S. and U.K. peers-hence the enhanced emphasis on academic "excellence".

A broad stream of literature in economics, education, management, sociology and other disciplines studies how these new demands have changed universities, and to what extent their interplay has resulted in conflicting objectives and unintended consequences. For instance, potentially adverse repercussions of knowledge transfer through the commercialization of university inventions have been explored widely (e. g., Murray and Stern 2007). Both performance-based funding and the shift toward academic "excellence" have remained highly controversial (Hartmann 2010; Welpe et al. 2015).

However, in spite of the vivid ongoing debate about new challenges faced by universities, and how addressing these challenges changes the university, the geographic dimension of the development has gained scant attention. But if the recent challenges change the university, they also have the potential to change its impact on regional development. Therefore, the articles brought together in the present special issue explore the regional effects of universities under the new prerogatives of science policy. Specifically, Koenig et al. (2017) study whether the excellence orientation in science policy poses a hazard to regional development objectives. Brökel and Roesler (2017) investigate the contribution of universities in regional collaboration networks in biotechnology, which form part of the new "third mission" of knowledge transfer.

Radinger-Peer and Pflitsch (2017) concentrate on another aspect of universities' third mission and study the contribution of Higher Education Institutions to the regional transition towards sustainability. Brenner and Pflitsch (2017) look at the opposite causal direction and examine whether research at universities - in this case research on sustainability-is influenced by local circumstances. While sustainability was originally a rather politically developed and propagated concept, it has become a central issue in many disciplines in the meantime. The political focus on this topic-expressed for example in the Global Sustainable Development Goals-has provided new impetus and new resources to this field.

In this context, sustainable regional development has become an important issue. The literature on regional sustainability transitions takes a specific perspective. In line with the concept of sustainability transitions (Geels 2004, 2011), it is argued that a systemic transition affecting various socio-technical regimes is necessary within the region (McCormick et al. 2013). Leadership plays a crucial role in such a transition (Horlings and Padt 2013). Whether local universities are able to take such a leadership role and how universities are involved in such processes at all is less researched so far and examined in the latter two papers included in this issue. 
This special issue has its origins in the working group Hochschulen und nachhaltige Regionalentwicklung ("universities and sustainable development") of the German Akademie für Raumforschung und Landesplanung (ARL). Established in 2014, this working group brought together researchers from various academic disciplines. The four articles in this special issue are outcomes of the collaborative research of the working group. They were discussed in the group meetings and benefited from the helpful comments of the other group members.

\section{The articles in this special issue}

The contribution by Johannes Koenig, Thomas Brenner and Guido Buenstorf (this issue) focuses on the increased emphasis on academic "excellence" and international competitiveness, which above was suggested as one of the recent challenges faced by universities. Specifically, the article explores whether policy makers' excellence prerogative leads to sharper regional imbalances in research funding. This would be particularly problematic if "excellence" was harder to attain for universities in economically disadvantaged regions and considerations of regional convergence and cohesion were compromised by the quest for excellence. The authors present theoretical considerations why university-level and regional characteristics may be associated with successful competition for merit-based funding. For the empirical context of Germany, they show that the regional concentration of Deutsche Forschungsgemeinschaft (DFG) funds further increased after 2005 when the German Exzellenzinitiative was initiated. They find that regions with larger overall university size obtain more than their proportionate share of DFG funding, and that this imbalance may have become stronger after 2005. However, neither urbanization nor stronger private-sector R\&D capabilities seem to be linked to regions' capacity to benefit from the policy shift toward academic "excellence" in Germany.

The contribution by Tom Brökel and Christoph Roesler (this issue) analyses the impact of policy programs focusing on the "third mission" of universities. It is well known in regional economics that certain forms of knowledge (tacit knowledge) are first developed and used regionally, mostly within the context of continuous networks based on trust and personal contacts. Starting with the observation of Alfred Marshall (1890) that the spatial concentration of companies generates advantages for all companies the classical concept of "industrial districts" was gradually expanded in regional economic theory culminating in the concept of "innovative milieus" (Camagni 1991) and "interorganizational collaboration" (Powell et al. 2005) with their emphasis on the process of knowledge generation and the building-up of innovation potential. For the case of subsidized R\&D networks in the German biotechnology industry, the authors find that universities are an essential part of regional knowledge networks acting as regional gatekeepers for inter-regional knowledge diffusion. They conclude that at least in the empirical context of their case study, the ongoing shift in university funding from a two-pillar model concentrating on research and teaching towards a three-pillar model concentrating on research, teaching and knowledge transfer seems to have the politically intended impact. 
Universities' contributions to the non-economic dimensions of sustainable regional development, i. e. social and environmental objectives, are at the center of the other two articles in this special issue. Verena Radinger-Peer and Gesa Pflitsch (this issue) examine the contribution of Higher Education Institutions (HEI) to the regional transition towards sustainability for the example of Linz. Hence, their article contributes to the understanding of the impact of HEI on regional institutional and organizational change, reflecting a broad interpretation of the "third mission". The article uses a case study approach based on a comprehensive documentary analysis and in-depth expert interviews. It shows that, indeed, HEIs are involved in the transition towards sustainability that is observed in the city of Linz. However, it is not the HEI itself that interacts with other actors and organizations, but specific individuals from the HEI are identified as engaging in sustainability and contributing to the transition. The authors moreover detect a substantial lack of collaboration among these individuals. Due to this lack of cooperation the HEIs in Linz do not fully utilize their potential to influence the development of their home region.

Thomas Brenner and Gesa Pflitsch (this issue) turn around the above research question and study where sustainability research is actually conducted. Following the lead of the debate on science-technology interactions, they challenge overly one-directional conceptions and suggest that sustainability research at universities is interdependent, and co-evolves, with civic attitudes and private-sector activities in the respective region. A mixed methods approach is used combining quantitative regression analyses with qualitative expert interviews. The aim of the article is to explain the heterogeneity in the share of publications on sustainability among German universities, and through this to understand the determinants of the research orientation of universities. In line with the paper before, individual researchers are found to be very independent, so that they mainly determine their research focus. Path dependence is strong on the individual level, but does also exist on the organizational level. Due to teaching and supervision and due to the choice of study and research locations by students, PhDs and researchers according to (research) interests, universities develop a certain research profile. No evidence is found for a strong impact of activities by the university board. Regional circumstances are also of minor importance, although some causal effects of the local attitudes (measured by Green party votes) and the innovation activity of the regional economy are found.

\section{Concluding remarks}

In 1989 Jaffe's pioneering econometric study on regional effects of university research was published. Thirty years later, many open questions remain about the role of universities in regional development, and particularly sustainable regional development. The objective of this special issue is to help answer some of these questions. But it can only be a small step on a long journey. Much more work remains to be done. Some topics that are taken up here require a comparison with other cities, topics or industries in order to check the results' generality. Further topics of interest in this context are, e.g., whether universities become more influential in their regions due to effort to make them more efficient, whether the changes in the study 
programs has an impact on the spatial distribution of qualified labor, or whether the support of excellence makes universities more or less willing to interact with the economy.

\section{References}

Acs ZJ, Audretsch DB, Feldman MP (1992) Real effects of academic research: comment. Am Econ Rev 82:363-367

Brenner T, Pflitsch G (2017) The raise of publications on Sustainability - a case study in Germany. Rev Reg Res

Breznitz SM, Feldman MP (2012) The engaged university. J Technol Transf 37:139-157

Brökel T, Roesler C (2017) The role of universities in subsidized R\&D networks: the case of the biotechnology-industry in Germany. Review of regional research. Rev Reg Res. https://doi.org/10.1007/s10037017-0118-7

Brundtland GH (1987) Report of the world commission on environment and development: "our common future.". United Nations, Oslo

Camagni R (1991) Innovation networks. John Wiley \& Sons, Hoboken

Chatterton P, Goddard J (2000) The response of higher education institutions to regional needs. Eur J Educ 35(4):475-496

Cowan R, Zinovyeva N (2013) University effects on regional innovation. Res Policy 42 (3):788-800

Dosi G, Llerena P, Labini MS (2006) The relationships between science, technologies and their industrial exploitation: an illustration through the myths and realities of the so-called 'European Paradox. Res Policy 35(10):1450-1464

Drucker J, Goldstein H (2007) Assessing the regional economic development impacts of universities: a review of current approaches“. Int Reg Sci Rev 30:20-46

Etzkowitz H, Leydesdorff L (2000) The dynamics of innovation: from national systems and "mode 2" to a triple helix of university-industry-government relations. Res Policy 29(2):109-123

Fritsch M, Slavtchev V (2007) Universities and innovation space. Ind Innov 14(2):201-218

Geels FW (2004) From sectoral systems of innovation to socio-technical systems - Insights about dynamics and change from sociology and institutional theory. Res Policy 33:897-920

Geels FW (2011) The multi-level perspective on sustainability transitions: responses to seven criticisms. Environ Innov Soc Transit 1:24-40

Hartmann M (2010) Die Exzellenzinitiative und ihre Folgen. Leviathan 38(3):369-387

Hazelkorn E (2009) Rankings and the battle for world-class excellence. High Educ Manag Policy 21(1):1-22

Hird MD, Pfotenhauer SM (2017) How complex international partnerships shape domestic research clusters: Difference-in-difference network formation and research re-orientation in the MIT Portugal Program. Res Policy 46 (3):557-572

Horlings I, Padt F (2013) Leadership for sustainable regional development in rural areas: bridging personal and institutional aspects. Sustain Dev 21(6):413-424

Hüther O, Krücken G (2016) Fragestellungen, Ergebnisse und Perspektiven der sozialwissenschaftlichen Hochschulforschung. Springer, Berlin

Jaffe A (1989) Real effects of academic research. Am Econ Rev 79(5):957-970

Kenney M, Mowery DC (eds) (2014) Public universities and regional growth: insights from the University of California. Stanford University Press, Palo Alto

Klepper S (2016) Experimental capitalism: the nanoeconomics of American high-tech industries. Princeton University Press, Princeton

Koenig J, Brenner T, Buenstorf G (2017) Regional effects of university funding: excellence at the cost of regional disparity? Review of regional research. Rev Reg Res. https://doi.org/10.1007/s10037-0170117-8

Marshall A (1890) Principles of economics. MacMillan, London

McCormick K, Anderberg S, Coenen L, Neij L (2013) Advancing sustainable urban transformation. J Clean Prod 50:1-11

Murray F, Stern S (2007) Do formal intellectual property rights hinder the free flow of scientific knowledge?: An empirical test of the anti-commons hypothesis. J Econ Behav Organ 63(4):648-687

Pike A, Rodriguez-Pose A, Tomaney J (2007) What kind of local and regional development and for whom? Reg Stud 41(9):1253-1269

Powell WW, White DR, Koput KW, Owen Smith J (2005) Network dynamics and field evolution: the growth of Interorganizational collaboration in the life sciences. Am J Sociol 110(4):1132-1205 
Powell WW, Packalen K, Whittington K (2012) Organizational and institutional genesis. In: Padgett JF, Powell WW (eds) The emergence of organizations and markets. Princeton University Press, Princeton, pp 434-465

Radinger-Peer V, Pflitsch G (2017) The role of higher education institutions in regional transition paths towards sustainability - the case of Linz (Austria). Rev Reg Res. https://doi.org/10.1007/s10037017-0116-9

Schubert T, Kroll H (2014) Universities' effects on regional GDP and unemployment: the case of German. Pap Reg Sci 1:1-24

Stephan PE (2012) How economics shapes science. Harvard University Press, Cambridge

Valero A, Van Reenen J (2016) The economic impact of universities: evidence from across the globe. NBER Working Paper 22501. National Bureau of Economic Research, Cambridge

Vogel R (2006) Zur Institutionalisierung von New Public Management. Deutscher Universitätsverlag, Wiesbaden

Welpe IM, Wollersheim J, Ringelhan S, Osterloh M (eds) (2015) Incentives and performance. Governance of research organizations. Springer, Berlin 